\title{
Impacts of COVID-19 Lockdown Restrictions on Housing and Public Space Use and Adaptation: Urban Proximity, Public Health, and Vulnerability in Three Latin American Cities
}

\author{
Raul Marino, Elkin Vargas and Mariana Flores
}

\begin{abstract}
This chapter presents the results of an investigation about the lack of access to public space and social interactions in three Latin-American cities by using literature review, location data and online survey (quantitative and qualitative information) from household members on how these restrictions affected their daily life and their relationship with community and public space use. Focused on Bogota, Quito, and Mexico DF $(n=650)$, geospatial tools are used to correlate the survey's respondents' answers with official COVID-19 reports from government. The results show the correlation between the number of contagions by zones and users' behavioral shifts in terms of housing and public space use and adaptation. This could support the efforts of communities and decision makers to improve public health standards, reduce vulnerability to COVID-19, improve their resilience and enhance urban proximity to essential services and public spaces.
\end{abstract}

\subsection{Introduction}

In order to mitigate and manage the incidences of the pandemic, the World Health Organization [1] suggests the management of reliable information, as well as the isolation associated with social distancing, hand washing and treatment in case of contagion. The risks of a pandemic increase when community health and wellbeing weakens, however, there is a high incidence of contagions in land use, life expectancy, displacement, climatic disability and poor air quality. Confinement has undoubtedly transformed everyday life [2].

For the present study, a descriptive and causality analysis was carried out to explore the impacts of the COVID-19 pandemic on housing and public space use and adaptation, based on a survey that was applied online in different countries, but focusing in three cities of interest: Bogota (Colombia), Quito (Ecuador) and Mexico City (Mexico). An innovative methodology was proposed using official data, our survey results and geospatial analysis. Geospatial analysis allows integrating themes in disease mapping such as spatio-temporal analysis, health and geography, environmental variables, data mining and web mapping, and understanding the spatial conditions of propagation for the design of mitigation strategies, in decision-making, planning and community action. The importance of geospatial analysis methodologies lies in the possibility of strategically identifying vulnerable 
sectors, either due to their location, services or nearby infrastructure, geographical conditions, or particularities in the case of informal settlements [3].

\subsubsection{Proximity and density}

The urban factors identified in the spread of the pandemic in Wuhan were the intensive urban growth, hospitals, shopping centres, mixed uses, the population ageing index and roads, among others, which evidenced the need for planning strategies focused on understanding the transmission of infectious diseases in urban settings $[4,5]$. Physical distancing as a health measure does not imply social distancing, which is why it suggests the proximity argument based on the dichotomy of "being in the place" and "being connected" [6]. The urban density allows numerous complex social and economic interactions, which are associated with prosperity by being close to work centres and services. Communities exhibit demographic and socioeconomic differences associated with vulnerability [7]. Urban density as a key metric of sustainability, can be defined as the proportion of the total number of inhabitants living within a delimited urban footprint of a city. Research indicates that inhabitants of a compact city with a higher urban density will be closer to others, which will make moving from one place to another more efficient and sustainable. Some indicators to measure urban density are the urban footprint, the total population, residential occupancy, parcel coverage, the height of the buildings, the efficiency of the plants, the occupancy level, and people per dwelling unit. Studies have revealed a number of benefits of compactness: more productivity; lower cost public services; greater social and economic mobility, as well as diversity; increased use of public transport; lower energy use and emissions; and improved health and wellbeing $[8,9]$.

The current pandemic suggests investigating how connectivity influences spread more than density, since large metropolitan areas are closely linked through economic, social and transport relationships, so dense areas may have better access to care facilities and further implementation of distancing policies and practices [10]. The most marginalized populations are seen to be more likely to get sick and die from being exposed to unequal conditions [11]. In terms of community, density is not related to infection rates and is inversely related to mortality rates [12].

\subsubsection{Vulnerability and public health}

COVID-19 has exposed urban structural weaknesses and inequalities, where health is the best element of cohesion to insert proposals for development and progress in contaminated communities. Due to their inability to access adequate medical care, transportation, and nutrition, socially vulnerable populations are at increased risk of health problems during disasters [13]. The greater degree of vulnerability is accompanied by demographic change, infrastructure, and governance, which is why the virus occurs mostly in more developed areas. In this case, migration, urban population growth, and high population density are important factors influencing the spread of disease. Associated with science and technological responses to COVID-19, it is necessary to integrate more critical and reflective analysis in addition to theoretical knowledge. According to Polko et al. [14], public space is an open and impartially accessible geographic dimension for all, which includes social interactions, subject to restrictions such as physical distancing, and is a key characteristic of a resilient city due to its ability to transform itself for health purposes of emergency, and the flexibility to adapt to new needs [14]. Urban designers seek to create places where people feel welcome, comfortable, and safe. In this way, urban residents experience nature most of the time at "the cognitive level of urban space", that is, at the level where "the people on the street" live in the city. The questions from architecture and urban planning in the face of the crisis are focused on how it will affect our relationship with public space [15-19].

\subsubsection{Accessibility, adaptation and resilience}

The adaptation processes include aspects of housing and the city such as morphology, spatial distribution, connectivity and resilience, where green areas represent important cores that are added to concepts such as proximity, access and quality [20]. Resilience provides an adaptive 
approach to environmental problems, natural hazards, and public health emergencies. At the urban context, resilience is understood as the ability of cities to absorb and respond to disasters through five dimensions: scale, structure, form, function and urban spatial network [21]. According to Urban Resilience Hub of United Nations, it is the "measurable ability of any urban system, with its inhabitants, to maintain continuity through all shocks and stresses, while positively adapting and transforming towards sustainability" [22]. Resilience allows a system to adapt to changes, regarding environment/ecology, infrastructure and governance/institutions. Meanwhile, accessibility considers access to urban and public services, health, food, financial resources, places, etc., for the entire population and vulnerable sectors [23].

\subsection{Case Studies Context Summary}

\subsubsection{México city, Bogota, and Quito: common urban realities}

For our study, we focused on three of the main Latin American capitals that have special conditions of interest for our research: Mexico City in Mexico, Bogotá in Colombia, Quito in Ecuador (see Figure 28.1). These cities share among each other similar economic, social, and cultural characteristics; moreover, some other particularities in common such as geographical and climatic condition as well as similar environmental challenges. We consider that a comparative approach between these cities would allow us to evaluate more in detail certain hypotheses related to relationship between the spreading and impact of the COVID-19 pandemic with geographic, environmental, social, and climatic variables. The data collected, apart from those by official sources, were obtained through an online global survey with emphasis on Latin American region, where the three study cities represent almost the $50 \%$ of the total surveys gathered $(\mathrm{n}=1538)$. Another reason for doing a comparative analysis is the possibility to identify the successes or failures of policies and regulations implemented by local governments in relation to pandemic and its behaviour, by setting up possible linkages between these data and the results with variables such as urban density, centrality and proximity.
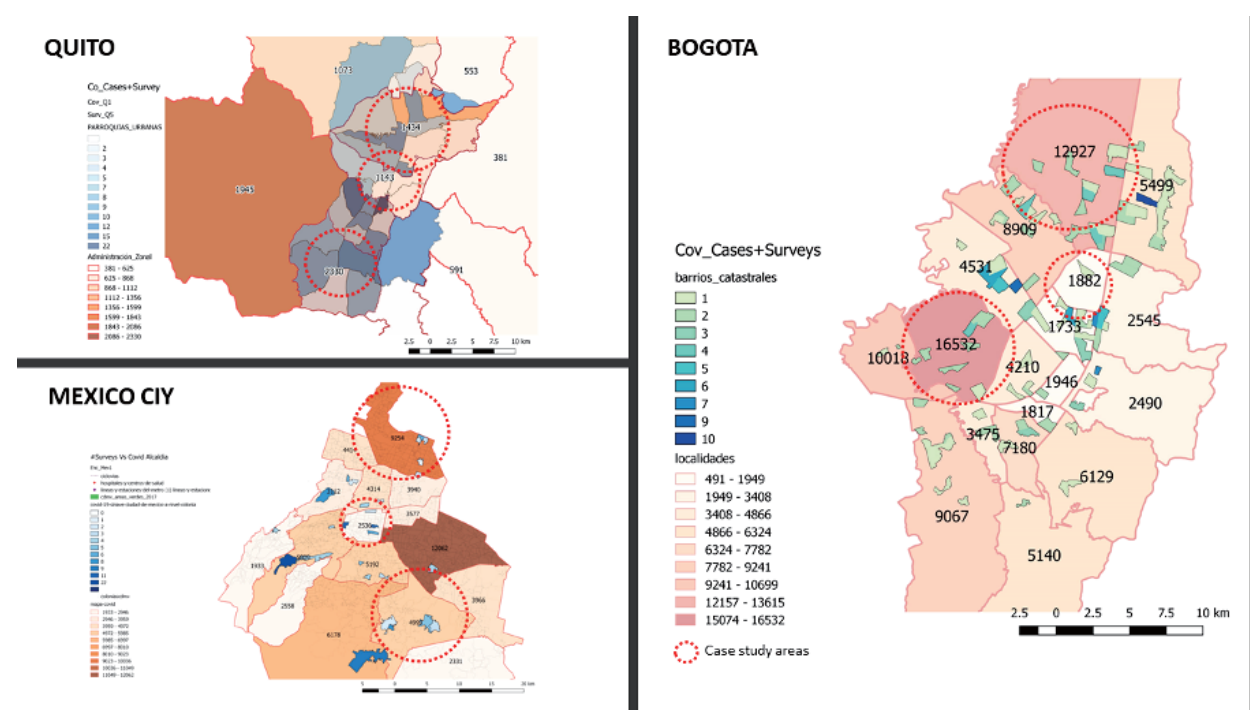

\section{FIGURE 28.1}

Case study cities: Quito, Mexico DF (left), and Bogota (right) - COVID-19 cases, survey participants and study area locations 
Other common characteristics among the three study cases are related to high altitude (Mexico City: 2200 mamsl while Bogotá and Quito are located at 2800 mamsl) and geographical and climatic conditions. These cities have been built up on wetlands surrounded by mountains, and in the case of Mexico City and Quito nearby to volcanos. Their urban humidity levels are quite similar as well as the climate, especially in Quito and Bogotá along the year because there are no seasons as in Mexico City. In terms of population and density (as indicated in Table 28.1), Mexico City is the largest with 8,928,653 inhabitants and a density indicator of $5,966 \mathrm{p} / \mathrm{km}^{2}$; Bogotá is the second in population with 7,181,469 inhabitants and the third in density with 4,907.45 p/ km²; Quito has 2,011,678 inhabitants and the second highest density rate among the three cities with 5,401.29 p / $\mathrm{km}^{2}$ after Mexico City (see Table 28.1).

\section{TABLE 28.1}

Comparative city data [24-26]

\begin{tabular}{|c|c|c|c|c|c|c|c|c|c|c|}
\hline City & Population & $\begin{array}{c}\text { Population } \\
\text { density } \\
\text { (pop/Km2) }\end{array}$ & $\begin{array}{c}\text { Covid-19 } \\
\text { cases } \\
(31 / 07 / 20)\end{array}$ & $\begin{array}{c}\text { Covid-19 } \\
\text { mortality } \\
\text { rate } \\
(31 / 07 / 20) \\
\end{array}$ & $\begin{array}{c}\text { Covid-19 } \\
\text { contagions } / \\
\text { million }\end{array}$ & $\begin{array}{l}\text { People per } \\
\text { household }\end{array}$ & $\begin{array}{c}\text { Public space } \\
\text { per inhabitant } \\
\text { (M2) }\end{array}$ & $\begin{array}{c}\text { Gini } \\
\text { coefficient }\end{array}$ & $\begin{array}{c}\text { Territorial } \\
\text { Administrative } \\
\text { Division }\end{array}$ & $\begin{array}{c}\text { number of } \\
\text { surveys }\end{array}$ \\
\hline Ciudad de México & $8,928,653$ & 5,966 & 76,169 & 8,731 & 8,530 & 3,4 & 5,4 & 0,532 & 16 (Delegaciones) & 158 \\
\hline Quito & $2,011,678$ & 5,401 & 13,438 & 640 & 6,679 & 3,5 & 21,6 & 0,492 & $\begin{array}{r}8 \text { (Administraciones } \\
\text { Zonales) }\end{array}$ & 325 \\
\hline Bogotá & $7,181,469$ & 4,907 & 101,955 & 4,900 & 14,196 & 2,8 & 4,5 & 0,504 & 19 (Localidades) & 184 \\
\hline
\end{tabular}

For the spatial analysis, two scales of analysis were selected: a Metropolitan scale and a municipality scale as it allows us to have a similar observation patterns in each of the three cities (see Figure 28.1). In this sense, Mexico City is divided into 17 sectors or "Delegaciones". In the case of Quito, the homologous territorial administrative division is called "Administración Zonal" with eight such subdivisions. Finally, in the case of Bogotá, the political-administrative unit is called "Localidad", with a total of 19 localities.

\subsubsection{Informality and public health}

One of the main common patterns in our three case study cities is urban informality. This concept is understood not exclusively from the economic perspective; informality is also related to spatial features. It is considered as a pattern of land occupancy that characterizes the Latin American city and the global south in general and shapes most of the marginal peripheries where a large percentage of low-income population lives [27]. From public space view, the street vendors add an activity buzz become a vital part of the urban, cultural and social landscape of many cities and towns in the Global South [28, 29]. Millions of households depend on informal economy, which mostly take place on public space [30]. Only in Mexico City, the informality rate is $49.7 \%$, that is, almost 5 out of 10 workers in the capital have an informal job [31]; a very similar indicator is shared by Bogotá [32] and Quito [26].

The impact of informality in public space becomes more complex during the current quarantine restrictions, as many street vendors are forced to keep crowding the streets as these are their only source of income. This risk increases in the case of Bogotá and Quito where large numbers $(450,000$ in Bogota alone) of migrant refugee population from Venezuela, is engaged in informal economic activities, as public vendors, increasing their vulnerability and contagions rates [33]. The policies of physical distancing and staying at home are not only difficult, they are often impossible to meet for large percentage of the population in developing countries [34].

Related to the current public health crisis, according to information available by 31 July 2020 (our baseline date), the impact of COVID-19 in terms of number of infections responds as follows: in Mexico City $^{1}, 76,169$ cases and 8,731 deaths (mortality rate: $11.5 \%$ ); in Quito ${ }^{2}, 13,438$ cases and

\footnotetext{
${ }^{1}$ https://datos.cdmx.gob.mx/pages/covid19/

${ }^{2}$ https://coe-pichincha. senescyt.gob.ec/wp-content/uploads/2020/08/Infografi\%CC\%81a-Cantonal-01_08_2020. pdf
} 
640 deaths (mortality rate $=4.8 \%$ ); in Bogotá $^{3}, 101,955$ cases and 4,900 deaths (mortality rate $=4.8 \%$ ). Additionally, on the basis of COVID-19 test taken per 100,000 inhabitants in each city, the city with the highest impact of virus spreading is Bogotá with 14,196 infections per million inhabitants, as indicated in Table 28.1.

In this sense, it is likely that the pandemic will push street vendors and other informal workers to a long-term economic recession without precedent in modern times. In fact, the recession will not be exclusively in terms of informal activities, the most of formal economic sectors are currently affected. However, informality, increases the state of emergency in Latin American countries where this sector represents around $40 \%$ of the labour force [35]. This condition in the global south and our case study cities makes even more important the capacity of reorganization and resilience of governments and communities in the face of current regulatory absence and political legitimacy crisis of governments, especially in Latin America.

\subsection{Research Methodology}

The analysis of the impacts of the COVID-19 pandemic were undertaken using a mixed methods approach, based on firsthand data collected by the authors through an online survey covering the three selected case study cities: Bogota, Quito and Mexico, and the results of a proximity analysis on Points of Interest (POI): public space, health facilities and public transport access (see Figure 28.2). So far, the analysis of the discussion of the impacts of the COVID-19 pandemic has been mostly focussed on secondary data or observations of public space use by researchers [36], with few published papers showing firsthand results. Also, most research on COVID-19 and the built environment has focused on either housing [10] or public space [37]. Only a small percentage of previous research addressed the integrated study of housing and public space.

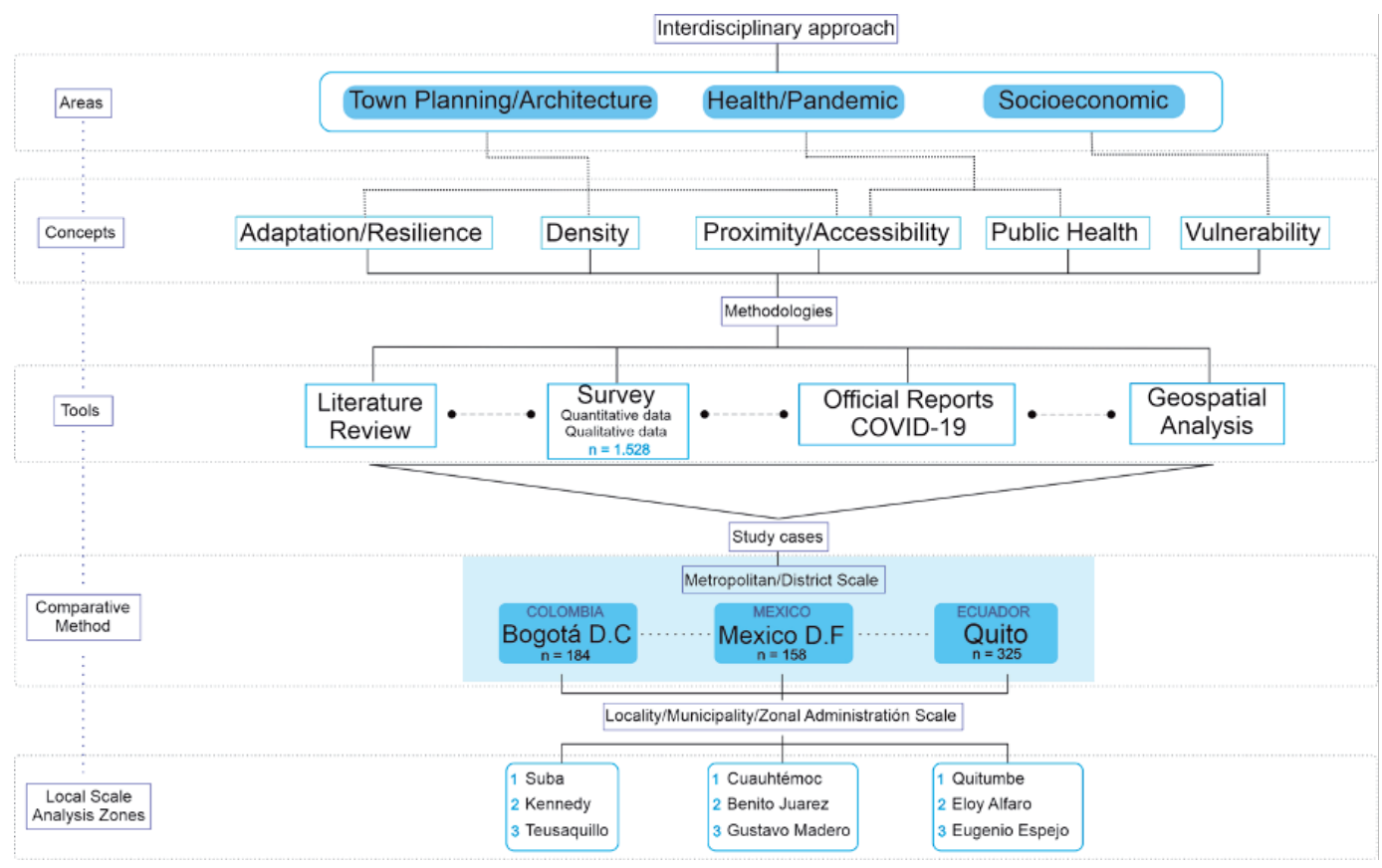

\section{FIGURE 28.2}

Research Methodology Scheme 1

\footnotetext{
${ }^{3}$ http://saludata.saludcapital.gov.co/osb/index.php/datos-de-salud/enfermedades-trasmisibles/covid19/
} 
Geospatial analysis has been used widely to understand the factors driving the contagion of cases in urban areas, from the first cholera cluster maps in the London Epidemic in 1854 done by Snow, to the use of advanced tools using artificial intelligence and advance algorithms calculations [38]. The challenges of public health management in the last decades had led medicine research to support itself with geographical analysis, especially GIS systems, to understand the development and trends of infectious diseases in urban and rural contexts [39]. Important discoveries related to patterns of incidence and spread of the some of the main diseases affecting human population such as cancer, diabetes and lung and heart problems, and their correlation with the urban form and structures of cities, their density and their access to public transport [40, 41].

Surveys have been used as a method to collect information on sociodemographic characteristics of urban population and their housing and mobility behaviour [42, 43]. Its focus change according to the information needs, from surveys covering all the population in a given city or urban area (census), to surveys focused on specific segments of the population (by age, income, housing type, etc) and also focused on specific areas of the city where a certain phenomenon or trends needs to be investigated [44]. Based on these experiences, this paper follows a mixed method of collection of the required data for our analysis (see Figure 28.2), integrating two analytic tools: the analysis of the results of the survey conducted by our team on impacts of quarantine in housing and public space use; and the geospatial analysis of the case study cities selected in this paper: Bogota, Quito and Mexico DF.

\subsubsection{Data collection}

The collection of data was performed using two approaches, an Online Survey and collection of COVID-19 contagions reports from our case study cities.

- Online survey: The online survey collected information about the impact of quarantine's restrictions on housing and public space and adaptation. The survey was open for any person or household currently (from 25 April to 31 July 2020) experiencing restrictions on their daily activities due to governments emergency regulations to COVID-19, such as curfews, lockdowns, mobility restrictions, and other. The survey was divided into 7 categories (socioeconomic profile, housing, community, public space, mobility, working/education, and public health), with a total of 42 questions and a running time of 14 mins. The questions were divided into multiple selection and questions with open-ended responses, to collect a wider variety of observations from the participants. The delivery system used was through academic and professional online networks from the main authors in several countries in Latin America, Europe, and Oceania, focusing on Colombia, Ecuador, and Mexico as main case study areas for this research. To access the online survey site please see: https://www.surveymonkey.com/r/urbanmappingagency-English

- Collection of COVID-19 data and geospatial data from the case study countries: The data and figures related to the number of COVID-19 cases per city and analysis zones were collected from the government's official portals (see Bibliography for references on COVID-19 Portals) and reports to the closing date of the study: 31 July 2020. It is important to mention that being this pandemic such a dynamic and changing phenomenon, from which we are still trying to learn its nature and behaviour, the reported COVID-19 cases reports from each country and city can differ from the real number on COVID-19 contagions [1].

\subsubsection{Data analysis}

The collected data was analysed following a mixed methods approach:

- Online survey: (a) Qualitative information: The collected answers were analysed using content analysis and sentiment analysis tools [45], looking to understand the opinions and experiences of the participants in front of the quarantine's restrictions. (b) Quantitative information: The quantitative data were tabulated and analysed using statistical analysis tools (SPSS and Minitab), however the results of this analysis will be presented in a separate follow-up report. 
- Geospatial analysis: This paper focused on the relationship of spatial variables such as density, accessibility and proximity to the points of interest: public space, health facilities and public transport hubs, and their relationship with the location of COVID-19 contagions clusters in our case study cities. The geospatial analysis tools used were selected to map and measure accessibility and proximity levels in a combined mapping of the local zones selected in each city. To achieve this, the Cost Distance tool [46] was selected to evaluate the accessibility and proximity to parks, health facilities and public transport hubs. To create the Cost Distance Maps, we converted the street network to raster format used Euclidean Distance tools to get the cost raster as an input parameter in cost distance tools.

- Limitations and assumptions: The study's limitations relate to availability of data for the case study cities, and possible small errors in the spatial files used to run the geospatial analysis. Also, the reports of the COVID-19 might have also misreporting information on the number and location of cases. The authors gave their best effort to minimize these errors.

\subsection{Results}

\subsubsection{Survey results (housing, public space, mobility, community)}

This section presents the results of the online survey and geospatial analyses described in Section 28.3, Methodology. The information is presented in the form of comparative figures, matrix of proximity mappings per case study city (see Figures 28.4, 28.5 and 28.6) and comparative table integrating all results (Table 28.2).

The online survey had a final number of 1,568 of complete answers by the cut-off date of 31 July 2020. The survey was opened to all persons or households experiencing quarantine restrictions in any city in the world, and the survey collected information from 38 countries and 121 cities (see COVID-19 preliminary Survey Report, 2020). From this complete sample $(n=1,568)$, the $45.6 \%$ corresponded to our three case study cities, with a sample of 189 complete answers in Bogota, 320 in Quito and 155 in Mexico DF. The survey collected information on the impact of the restrictions of the COVID-19 pandemic in housing and public space use and adaptation, including information about impacts on mobility, community, working and education. In this chapter, we focus on the results related to public space use, mobility, and community responses to the crisis. More information about the survey's results on housing use and adaptation can be found in the preliminary report cited above.

Changes in house use and restrictions to access public space have an impact as well in the change of use of public space, driving shifts in behaviour and mobility [47]. Most of the participants in the three case study cities (65.18\%) expressed that they make some changes in the use of the houses, in response to the restrictions imposed by the quarantine. Studies in Mexico and Bogota also arrived at similar conclusions $[48,49]$. This number indicates that the restrictions are having a profound impact on the life of people and families, which should be further investigated to provide a better quality of life in the face of new conditions arising from COVID-19 pandemic.

Housing flexibility is one of the main factors that enable rapid adaptation to new living and working conditions. When asked about their houses' flexibility to adapt to new uses such as working and education, $46.3 \%$ of the participants indicated that their houses did not have flexibility to cope with the change of lifestyles and permanent cohabitation with the other members of their family groups or households. Therefore, it is essential that governments and institutions provide guidelines for housing adaptation to new uses such as working, education, gym and others, and also promote the development of new housing typologies that could adapt faster to the needs of their inhabitants and be more resilient to the impacts of the pandemic.

One of the main impacts of the COVID-19 pandemic has been the lack of face-to-face interaction with other community members. This increased the cases of psychological stress and depression on populations under severe quarantine restrictions. Question 32 of the survey asked participants 
which activity in public space they missed the most, and $35.7 \%$ of the participants expressed that it was the lack of social interaction with other people in public space, followed by walking (19.9\%) and working out in public space/parks (14.3\%). The survey also asked about the impact of the lack of social interaction on the participants' mental health and $81 \%$ indicated have some alteration to their mental health, mainly anxiety, irritability, and depression. These findings are similar to the ones presented by some surveys and studies on the same topic, which described the lack of social interaction as one of the main impacts on people's health during the COVID-19 pandemic [37, 50].

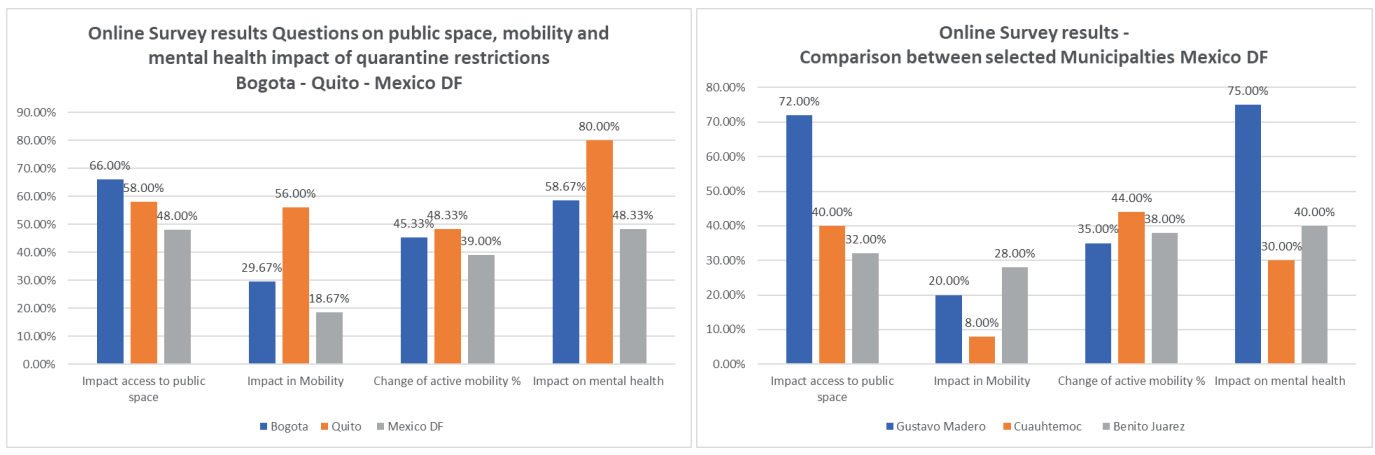

\section{FIGURE 28.3}

Online survey results comparison - Case Study cities analysis areas average (left) and results for Mexico City (right)

Access to public space and green areas is vital for the social and community life of cities [51]. According to survey results, $74.5 \%$ of the participants have a park or green area close to their homes $(500 \mathrm{~m})$, and the $52.4 \%$ expressed being affected by the restrictions in access and use of public spaces such as parks, recreation areas, public gyms and playgrounds (see Figure 28.3). This indicates that the strategies to manage the impacts of the COVID-19 pandemic in cities should consider more actively how to keep open these vital infrastructure, instead of just closing all parks and green areas as many cities in the world did (including our case study cities). The lack of access to public sport facilities and gyms had also created rising problems in public health, accelerated by the sedentarism of homeworking and home-schooling [36].

\subsubsection{Geospatial analysis results (proximity, accessibility, density, etc.)}

This section presents the results of the geospatial analysis of the selected variables (proximity, accessibility, density) in our three case study areas. The results are presented in a matrix of maps per case study to facilitate the comparison amongst the three selected local areas. As described above, our three-case study Metropolitan Areas (Bogota, Quito, Mexico), were analysed at municipality level, to enable a finer grain analysis of the urban conditions of each zone. These three subdivisions for each Metropolitan area are: Bogota (Kennedy, Suba, Teusaquillo), Quito (Espejo Alfaro, Eugenio Espejo and Quitumbe) and Mexico DF (Gustavo Madero, Cuauhtemoc and Benito Juarez). The results are described briefly in this section and will be analysed in more detail and compared with the survey information in the next section, Discussion.

In general, the three areas selected show a degree of lack of proximity to public space (parks), health facilities, and public transport. Proximity to Public Transport was more evenly distributed in Quito and Mexico, with large areas of Bogota's analysis zones showing a lack of accessibility to the BRT Transmilenio system (specially in Kennedy and Suba localities). The following part presents the results of these analyses per city in a comparison matrix. To see more details in each of the maps, please see: https://burodap.co/project-details/habitar-bajo-condiciones-de-cuarentena

In the case of the three analysis zones in Bogota, the analysis show that there are large contrasts amongst them, with localities such as Suba containing large areas that are not covered by public transport system, health facilities and have no parks (see Figure 28.4). One of the reasons for these 
TEUSAQUILLO
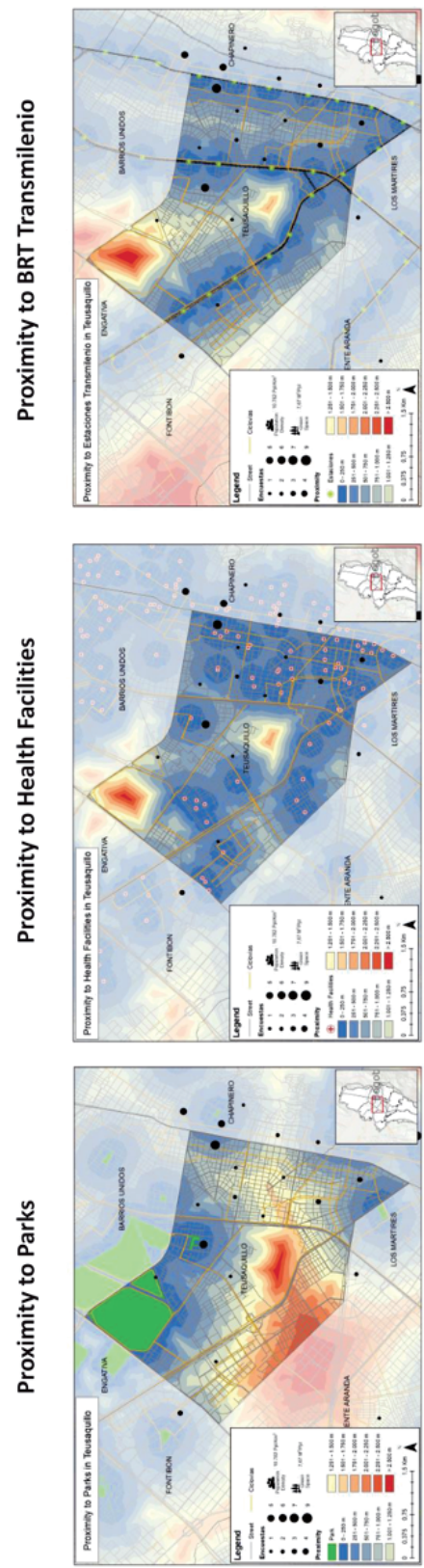

KENNEDY
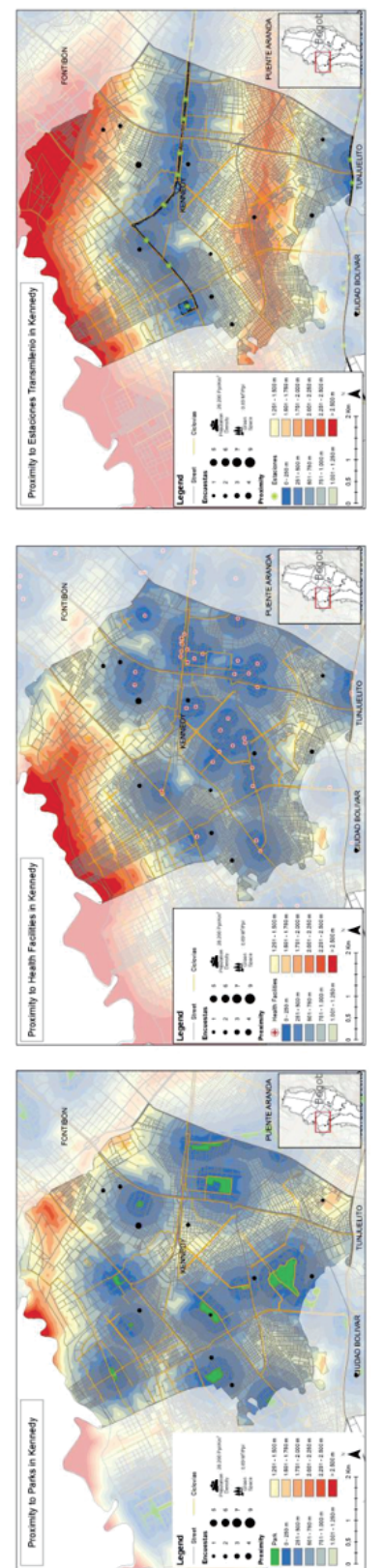

SUBA
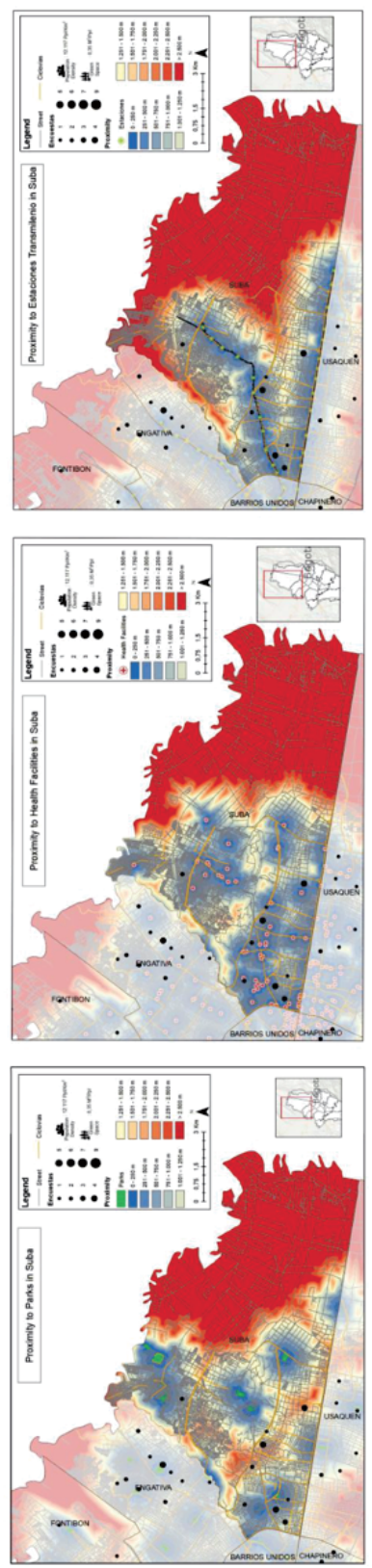

\section{FIGURE 28.4}

Geospatial proximity analysis Bogota (Kennedy, Suba, Teusaquillo)

results can be that a large part of the north part of Suba locality is a protected reservation zone which contains some small industries, and very low population density.

The selected zones In Quito also showed differences in proximity to parks, health facilities and public transport (see Figure 28.5). However, these differences were smaller than our other 
ELOY ALFARO
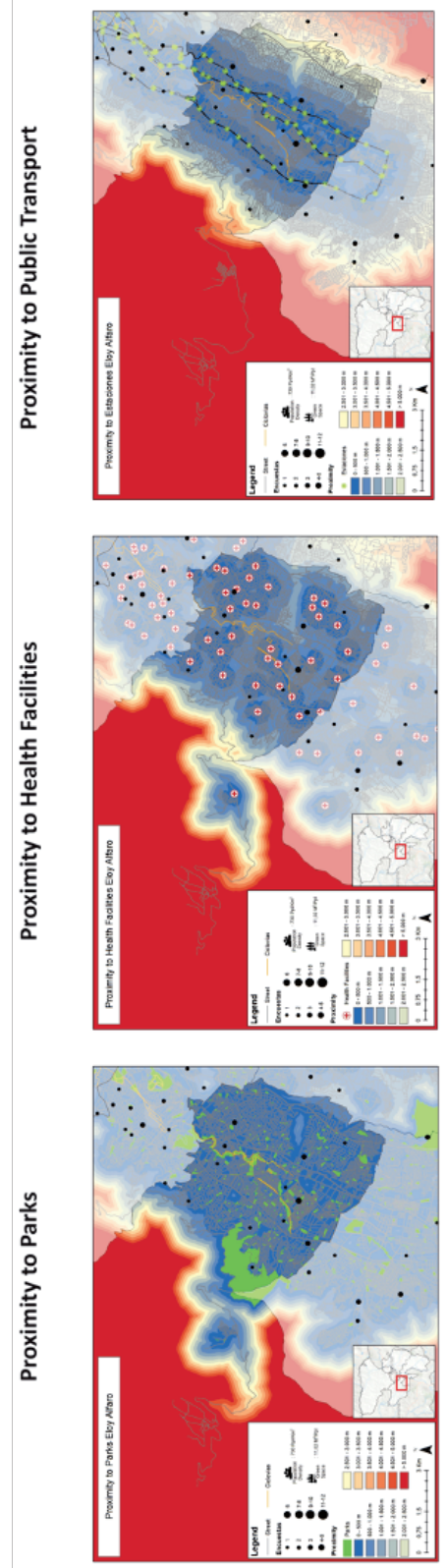

\section{EUGENIO ESPEJO QUITUMBE}
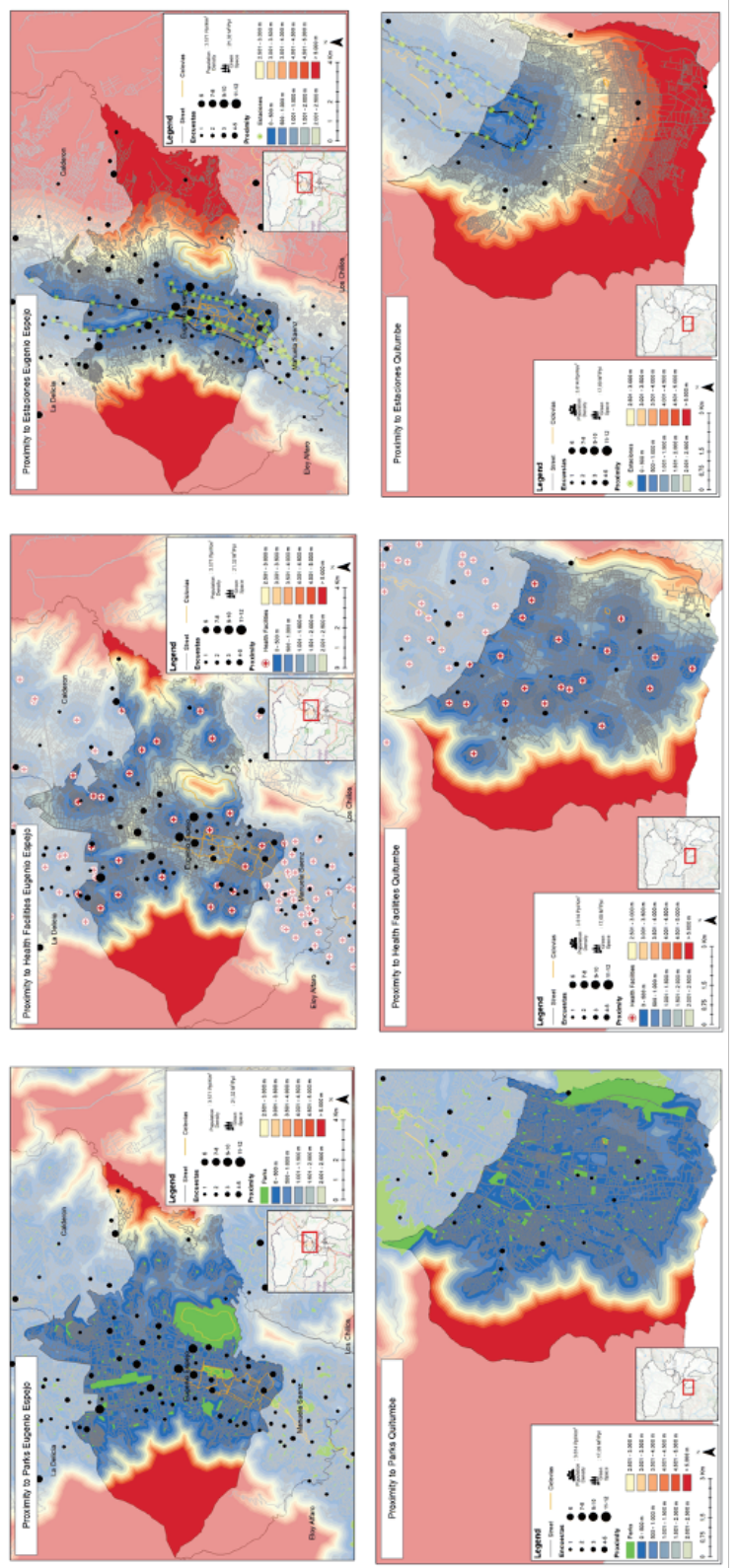

\section{FIGURE 28.5}

Geospatial proximity analysis Quito (Eloy Alfaro, Eugenio Espejo, Quitumbe)

case study cities, which can be related to the smaller population size in Quito, together with a denser distribution of population driven by the geographical features of the mountains conforming the metropolitan area of Quito. In some of the selected administrative zones, the analysis show a higher lack of accessibility to these infrastructure, which can also be related to the land use classification in these areas, which are more of an urban-rural character located at the periphery of the city. 
BENITO JUAREZ
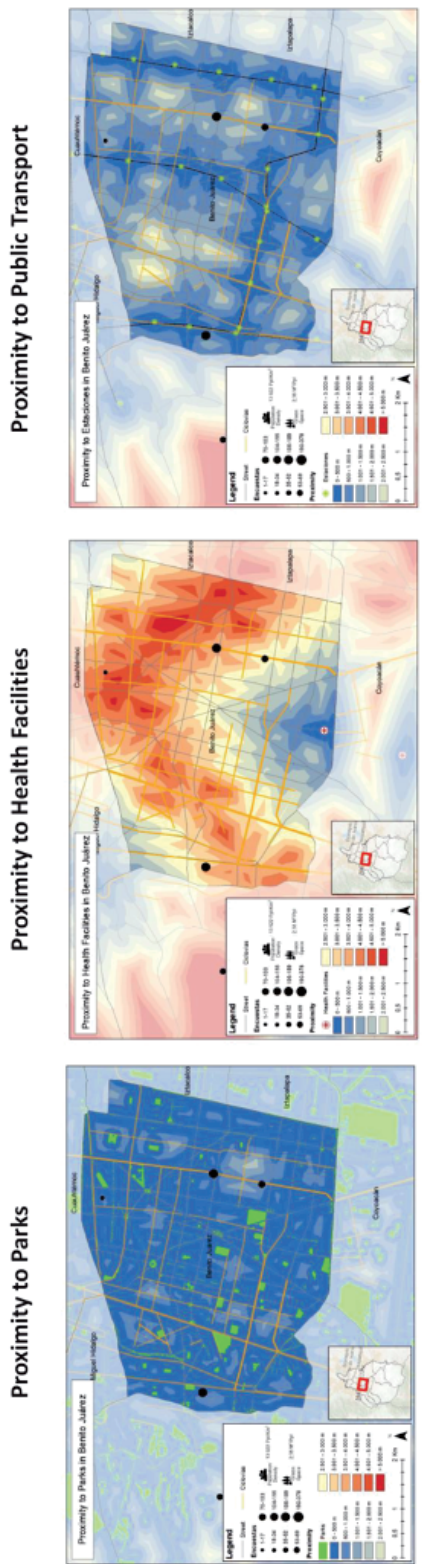

CUAUHTEMOC
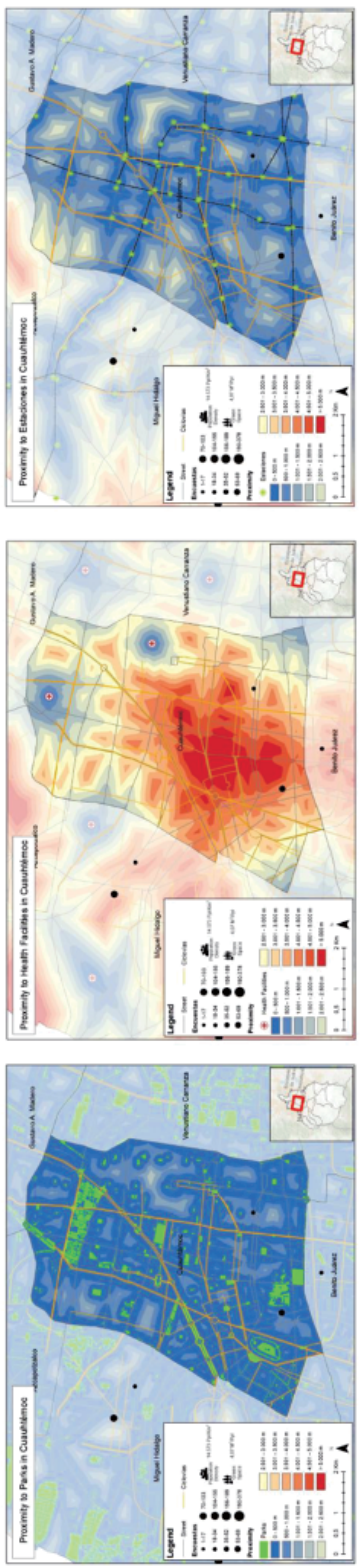

GUSTAVO MADERO
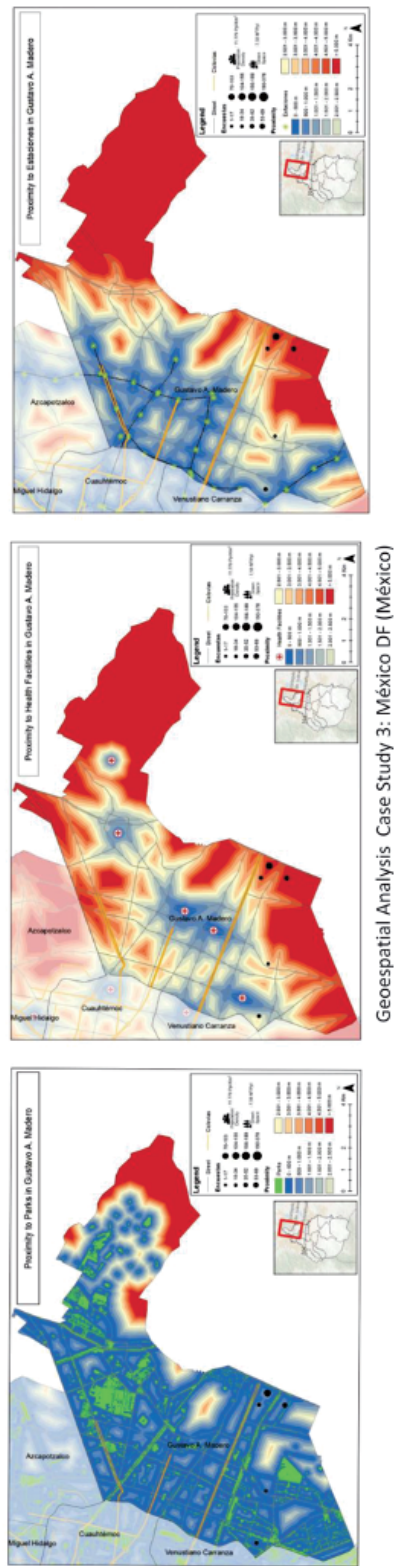

\section{FIGURE 28.6}

Geospatial proximity analysis Mexico City (Benito Juarez, Cuauhtemoc, Gustavo Madero)

For Mexico, the three municipalities selected showed a larger lack of accessibility to health facilities, but also have a better distribution of green areas and parks than our other case study cities (see Figure 28.6). One of the municipalities analysed, Gustavo Madero, displayed a lower coverage of public transport network, especially in the north part, which is located at a peripheral area of the city and mostly consisting of low-income households. 


\subsubsection{Integration of survey and geospatial results}

The areas of analysis in each city were selected considering their number of COVID-19 cases, and also the urban characteristics of the areas, with areas located close the city centre and other located at the peripheries, with the aim to cover a larger variety of urban configurations. Also, the selected areas were considered related to the number of survey participants located in these areas, to be able to compare our survey results about the experience of users in public space and mobility during the restrictions of the COVID-19 quarantine. The maps of the geospatial analysis shown in Figures $28.4,28.5,28.6$ above display the survey's participant number in a black circle magnitude scale (the larger the circle more surveys according to scale in the legend) (see Figures 28.4, 28.5, 28.6 from one result to nine or more results. These results were geolocated using the survey's information on location of the participant (neighbourhood), collected in Question 13. The following section will discuss first the results of this survey in each city related to the use and changes in public space and mobility, and secondly, it will discuss the results compared with the result of the geospatial analysis of proximity to parks, health facilities and public transport for each selected zone in the case study cities.

TABLE 28.2

Integration of Survey and proximity analysis results per case study cities and localities

\begin{tabular}{|c|c|c|c|c|c|c|c|c|c|c|}
\hline \multirow[b]{2}{*}{$\begin{array}{c}\text { Area of analysis per } \\
\text { city }\end{array}$} & \multicolumn{2}{|c|}{ Density/Public space } & \multicolumn{3}{|c|}{ Geospatial Analysis results } & \multicolumn{4}{|c|}{ Online Survey Results } & \multirow{2}{*}{\begin{tabular}{|c|}
$\begin{array}{c}\text { Covid19 } \\
\text { Reports }\end{array}$ \\
\\
Covid Cases 31 \\
july/2019
\end{tabular}} \\
\hline & $\begin{array}{l}\text { Pop. Density } \\
\text { (pop/km2) }\end{array}$ & $\begin{array}{c}\mathrm{M}^{2} \text { parks per } \\
\text { person }\end{array}$ & $\begin{array}{c}\% \text { Proximity } \\
\text { Parks }(1500 \mathrm{~m})\end{array}$ & $\begin{array}{c}\text { \% Proximity } \\
\text { Health (1500 } \\
\mathrm{mt})\end{array}$ & $\begin{array}{c}\text { \% Proximity } \\
\text { Public } \\
\text { Transport } \\
(1500 \mathrm{~m})\end{array}$ & $\begin{array}{l}\text { Impact access } \\
\text { to public space }\end{array}$ & $\begin{array}{l}\text { Impact in } \\
\text { Mobility }\end{array}$ & $\begin{array}{l}\text { Change of } \\
\text { active } \\
\text { mobility }\end{array}$ & $\begin{array}{c}\text { Impact on } \\
\text { mental } \\
\text { health }\end{array}$ & \\
\hline Bogota & & & $71.74 \%$ & $76.92 \%$ & $62.59 \%$ & $66.00 \%$ & $29.67 \%$ & $45.33 \%$ & $58.67 \%$ & $107826 *$ \\
\hline Kennedy & 28206 & 0.69 & $93.34 \%$ & $83.35 \%$ & $58.16 \%$ & $70.00 \%$ & $39.00 \%$ & $52.00 \%$ & $62.00 \%$ & 16532 \\
\hline Suba & 12117 & 0.35 & $41.30 \%$ & $50.29 \%$ & $34.08 \%$ & $65.00 \%$ & $35.00 \%$ & $43.00 \%$ & $67.00 \%$ & 12927 \\
\hline Teusaquillo & 10782 & 7.67 & $80.57 \%$ & $97.11 \%$ & $95.52 \%$ & $63.00 \%$ & $15.00 \%$ & $41.00 \%$ & $47.00 \%$ & 1733 \\
\hline Quito & & & $39.71 \%$ & $21.99 \%$ & $25.60 \%$ & $58.00 \%$ & $56.00 \%$ & $48.33 \%$ & $80.00 \%$ & 9450 \\
\hline Eloy Alfaro & 13100 & 11.02 & $7.60 \%$ & $6.90 \%$ & $5.03 \%$ & $60.00 \%$ & $42.00 \%$ & $50.00 \%$ & $90.00 \%$ & 1945 \\
\hline Eugenio Espejo & 3571 & 21.32 & $70.29 \%$ & $57.47 \%$ & $34.89 \%$ & $63.00 \%$ & $46.00 \%$ & $40.00 \%$ & $70.00 \%$ & 1434 \\
\hline Quitumbe & 3614 & 17.09 & $41.23 \%$ & $1.60 \%$ & $36.89 \%$ & $60.00 \%$ & $80.00 \%$ & $55.00 \%$ & $80.00 \%$ & 2330 \\
\hline Mexico DF & & & $93.59 \%$ & $19.67 \%$ & $69.03 \%$ & $48.00 \%$ & $18.67 \%$ & $39.00 \%$ & $48.33 \%$ & 76169 \\
\hline Gustavo Madero & 11779 & 7.58 & $81.03 \%$ & $9.07 \%$ & $28.09 \%$ & $72.00 \%$ & $20.00 \%$ & $35.00 \%$ & $75.00 \%$ & 9254 \\
\hline Cuauhtemoc & 14572 & 4.07 & $99.88 \%$ & $42.24 \%$ & $89.36 \%$ & $40.00 \%$ & $8.00 \%$ & $44.00 \%$ & $30.00 \%$ & 4314 \\
\hline Benito Juarez & 13992 & 2.38 & $99.87 \%$ & $7.71 \%$ & $89.64 \%$ & $32.00 \%$ & $28.00 \%$ & $38.00 \%$ & $40.00 \%$ & 2536 \\
\hline
\end{tabular}

Table 28.2 shows the integration of the results of the proximity analysis to our POI (parks, public transport, and health facilities). The values represented in each cell in the geospatial analysis section represent the percentage of the municipality area that have access to the interest point within 1,500 $\mathrm{m}$. This range was selected as a class measure based on different urban planning studies supporting the development of 15-minute city in Paris [52] the 20-minute city in Melbourne [53], and the 20-minute neighbourhood in UK [54]. These plans promote the idea of a closer integration of activity hubs in the city subcentres, advocating for a better land use and reducing sprawl, increasing active transport (walking, bicycle) and reducing the need for long commuting to work, education, shops and recreational activities. The second part of the table shows the results of the survey's questions related to: impact of lack of access to public space, impact of mobility restrictions, shift towards active transport and impact on mental health. The values presented in these cells represent the percentage of the respondents in each city that indicate being affected by the restrictions of the quarantine in these activities. The last column presents the COVID-19 confirmed cases per city, as presented by official reports (see references in Section 28.2). 


\subsubsection{Statistical analysis: Multiple Linear Regression analysis results}

The results of the proximity analysis were analysed using multiple linear regression analysis approach, with a backward stepwise tool to run several iterations of the data to find the best fit. The regression had our variables of interest (proximity, density, accessibility) as predictors (expressed as Proximity to Parks, Proximity to Health Facilities, Proximity to Public Transport and population density), and the amount of COVID-19 cases reported in our baseline data (31 July 2020), as dependent variable. The first round of the stepwise analysis showed that the variables Proximity to Health Facilities and population density did not have a significant impact on the dependent variable, so they were removed from the regression. The results of the final regression are shown in Table 28.3:

TABLE 28.3

Multiple Linear Regression analysis results

\begin{tabular}{l|l|l|l|l|l|l|l|l|}
\hline \multicolumn{2}{l|}{ Coefficient Table Iteration $\mathbf{3}$ (adjusted R-squared = 0.737) } & & & & & \\
\hline & Coeff & SE & t-stat & $\begin{array}{l}\text { lower } \\
\text { to.045(5) }\end{array}$ & $\begin{array}{l}\text { upper } \\
\text { to.955(5) }\end{array}$ & Stand Coeff & p-value & VIF \\
\hline b & 3.819534 & 0.120283 & 31.754476 & 3.567200 & 4.071869 & 0.00000 & $5.81668 \mathrm{e}-7$ & \\
\hline $\begin{array}{l}\text { Log(X2) M2 } \\
\text { Public } \\
\text { Space }\end{array}$ & -0.562034 & 0.123662 & -4.544935 & -0.821455 & -0.302612 & -0.857770 & 0.00614089 & 1.081498 \\
\hline $\begin{array}{l}\text { Log(X3) } \\
\text { Prox.Parks }\end{array}$ & 1.216468 & 0.509843 & 2.385967 & 0.146901 & 2.286035 & 1.061661 & 0.0326999 & 3.011498 \\
$\begin{array}{l}\text { Log(X5) } \\
\text { Prox. Public } \\
\text { Transport }\end{array}$ & -1.112501 & 0.456156 & -2.438859 & -2.069442 & -0.155560 & -1.098922 & 0.0487361 & 2.164527 \\
\hline
\end{tabular}

As the results in Table 28.3 show, the selected research variables have a reasonably good fit for the model with an adjusted $\mathrm{R}^{2}$ of 0.737 . Public space per person $(\mathrm{p}=0.006)$, Proximity to Public Transport $(\mathrm{p}=0.058)$ and Proximity to Parks $(\mathrm{p}=0.0062)$ are significant predictor variables.

\subsection{Discussion}

\subsubsection{Main findings of analysis}

The three case study cities showed some similarities related to the patterns of contagions concentration, with peripheral areas of Bogota, Quito and Mexico DF registering the largest number of COVID-19 contagions. Also, when viewed separately, the patterns of proximity to the POIs (parks, health facilities and public transport) showed that these peripheral areas also have the lowest levels of proximity to the POI, especially in public transport accessibility and health facilities, indicating that there is a correlation between the access to these POI and the clustering of contagions in the local level areas analysed in each city.

Working and study activities have been also affected by the restrictions of the quarantine, shifting towards an online working, and learning model. $78 \%$ of the surveyed households have one member working remotely, $38 \%$ two members and $11.97 \%$ three members. This indicates the large amount of people that needed to adapt their houses to be able to work from home, with households having more than one member working at the same space, which creates problems related to privacy, concentration, noise and others. Regarding online education, the $63 \%$ of participants have one or more people learning online, and the $38.7 \%$ expressed having similar problems to be able to perform these activities in their homes.

The unit of spatial analysis in the three case study cities was based on certain criteria such as socio-economic and infrastructure characteristics of neighbourhoods and its densities. In this way, we classified the study sectors according to their urban proximity to our POI in low, medium, or 
high level. In the case of Bogotá, the sector or locality with the best indicators of proximity is Teusaquillo, based on proximity to health service infrastructure, public spaces, and connectivity with the rest of the city (see Table 28.2). It is followed by the Suba sector and in third place we see the Kennedy sector, which coincides with the highest contagion rate and population density despite of having a good proximity average to public spaces, health facilities and transport services. In this regard, it seems that high population density plus a weak socioeconomic condition are the aspects that might be more directly correlated with the high number of infections in these sectors.

It is worth noting that when comparing the three areas across the case study cities, with the highest urban deficits in the three cities, we find out that it coincides with the highest COVID-19 contagion rates, but also in terms of proximity as they are the most disconnected and distant from the public transportation system; especially in Quitumbe (Quito) and Gustavo Madero (Mexico). Although this last sector is not the most public transport deficient in Mexico City, it matches with Quitumbe in Quito regarding the impact of mobility and proximity to health infrastructures. On the other hand, the sectors of Teusaquillo (Bogotá), Eugenio Espejo (Quito) and Benito Juarez (CDMX), register the least contagion rate and the best indicators of proximity to POI and socioeconomic conditions. They are also the ones with the lowest population density. However, when comparing these proximity results with the results of the survey, these same three sectors, being the most favoured in this research, reflect the greatest impacts and limitations on access to public space and mobility. Several reasons could be offered for this contrast, mainly related to the strict quarantine restrictions enforced in the case study cities which restricted access to most public parks, playgrounds, and other communal facilities.

In the case of middle-income sectors, such as Suba (Bogotá), Eloy Alfaro (Quito) and Cuauhtemoc (Mexico), the greatest impact due to restrictions is connected with the lack of access to public space, according to qualitative data from online survey, despite the fact that the indicator of proximity to parks remains high in the study sectors of Quito and Mexico. On the other hand, one of the most revealing indicators among these sectors is observed in the percentage of people who answered affirmatively to the question about the impact of quarantine on their mental health. In this field, it is evident that the most affected population corresponds to residents of the sectors with higher population densities and those who have less access to parks or green infrastructure. Taking this into consideration, the sectors with closer proximity relationships to public space, transportation and health facilities show a lower impact on the mental health of their residents.

Density of population is another factor that has been investigated in relation with COVID-19 contagions rates [10]. Some research show that there is no or little correlation between density and the number of cases [55]. However, some factors associated to urban density, such as pedestrian congestion and crowding in public space and public transport could increase the contagion cases. In our survey, $52.35 \%$ of participants think that density is an important risk factor, while $32.34 \%$ expressed that density was an important factor, but there were other more important such as urban hygiene, crowding avoidance, access to health facilities and social behaviour to follow the norms stablished in each city to manage the pandemic. In comparison Table 28.2, the municipalities with largest density had higher register of COVID-19 cases in each city. Also, when comparing the results of the proximity to parks and public transport we noticed that with less proximity to these areas, the rate of COVID-19 contagions tends to increase. However, this was not true for all cases in our case study cities, as some municipalities such as Gustavo Madero in Mexico City had a high proximity value but also higher COVID-19 cases in the city.

Regarding the concept of urban proximity investigated in this research, one of the important findings has to do with the relationship among community, neighbourhood or districts with public space access, and the amount of public space area per person (parks and squares). These kinds of urban infrastructures have an influence in quality of life and public health when there is a close proximity relation between them and residential areas in the case study cities. In this sense, we notice a close correlation of a high contagious rate with the lack of proximity between urban health facilities to housing or residential zones. Additionally, there is also a difference between the case study cities of this type of health infrastructure in terms of service coverage and concentration with the health system in each of the three countries. For instance, the health system in Colombian cities is financed by public resources but outsourced by private operators. On the other side, in Mexico and Ecuador the public sector is still the main operator of health services, therefore most 
of the health facilities are centralized and managed by the public sector, consequently the coverage of health infrastructure is less dispersed along the city and more concentrated in large hospital complexes and multipurpose medical buildings.

Urban mobility has been also greatly disturbed by the restrictions of quarantine. $36 \%$ of the survey's participants in the case study cities expressed being affected in their mobility, and $74 \%$ report changing their transport modes towards more active transport such as walking and bicycling. On the other hand, $23 \%$ of the participants said that they would prefer to use private car to avoid any risk of contagion in public space. This shift towards active transport is an important trend that could support a change in urban transport planning, favouring bicycle networks and walkable pathways into the city's mobility infrastructure. Regarding these networks, $54 \%$ of the participants said that their cities did not have a bicycle network system, and $11 \%$ reported that such systems were currently under constructions in their cities.

Cities have adopted different strategies to manage the spread of the COVID-19 pandemic, mainly based on restrictions of mobility and agglomerations in public transport and public space. In this sense, our survey asked the participants about what strategy could be more effective to manage the reduction of contagions, and $25 \%$ expressed that the option: "Establish body temperature check point, hand washing stations and disinfectant gel in public space" was the best option, followed by the option: "Promote active transport and the expansion of bicycle networks and walkable paths", with $19 \%$, and finally the option: "Redesign public space, urban furniture and green areas to reduce human contact" $(16 \%)$. These results indicate that most in the urban communities wish to participate in the decision making process regarding the management of this pandemic, and is keen to support the development of active transport options and the redesign of public spaces to offer a safer environment for themselves, their families and the community. Participatory GIS options to collect community feedback on public space use and behaviour could be a valuable tool to support achieving this goal and offer better guidance to city planners in their quest to reduce the spread of the COVID-19 virus while reducing vulnerability in urban communities [56].

\subsubsection{Main findings and links to similar COVID-19 studies or reports}

Similar studies using online surveys to collect information about the impact of the COVID-19 pandemic restrictions on the life and behaviour of people and household have been published recently [37, 49]. The report presented by Gehl et al analysed the changes in the patterns of use and behaviour in public spaces in four Danish cities (Copenhagen, Helsingør, Horsends and Svenborg) and found that these cities are being used more for recreation, play and exercise, and the use of public space has remained constant, while A to B movements have decreased significantly. Similar results were found in our study regarding reduction of daily travels, however, the use of public space diminished during the pandemic in our case study cities, especially in Bogota. Another interesting observation of this study is that more children and older people are using the city's space than before. However, it is important to point out that the patterns of use and restrictions on the access and use of public space between Europe and Latin America are different, as most Latin-American cities have enforced strict restrictions to access parks, playgrounds, public gyms and other community areas. This is also supported by the results of the Google Community Reports on public space use [57] where it shows an increase of use in European cities $(+85 \%)$ and a large decrease of public space use in our case study countries $(-45 \%)$. This change can be driven by different factors, from the restrictions itself to access these spaces, to the change of attitude of people and community towards public space, considering it is now a risk area where there may be a higher probability of COVID-19 contagion [36].

\subsubsection{Impact of findings on COVID-19 strategies and planning}

As the results of the survey showed, and supported by similar reports [37, 58] in other cities, there is a significant shift towards active mobility (walking, bicycle) in cities in many countries, which could in turn increase the need for new strategies directed to increase and/or extend existing infrastructure to support this change of mobility patterns. On the other hand, there is also the risk that the low demand for public transport (already reported by several cities such as NY, Bogota 
and Quito), could create economic challenges in the provision and operation of public transport networks, increasing as well the use of private cars as main transportation mode in cities [47]. Urban pollution had decreased as well as collateral effect of the restrictions in mobility, and large percentage of the population currently working and learning from home in the case study areas (65\%), according to the data collected in our survey. The tendency towards these kinds of remote working and education has already being growing before the COVID-19 pandemic, and now has accelerated. This trend will likely continue, changing the way our cities and houses function.

Another possible scenario on the future growth of cities could be the increase of urban sprawl driven by the desire of larger housing spaces in low density neighbourhoods. In our survey, $24 \%$ of the participants expressed their preference for larger houses located far from the city centre. It is important that this tendency does not become a new wave of unsustainable expansion of cities towards their fringe areas, reversing the efforts of many cities towards better land use, with medium density mix-use areas located in strategic areas or activity clusters in cities, which had proven to be beneficial to reduce impacts of sprawl, pollution, energy use and promote an active community life $[59,60]$.

Communities have shown a great capacity to support groups vulnerable to the pandemic (migrants, street dwellers, the elderly, children), and a variety of responses have been received that show the potential that communities have to be an important part of management of the pandemic. However, citizen participation in decision-making about the management of this pandemic has been very low or non-existent in the study cities, as well as in many cities in the world.

\subsubsection{Recommendations for decision-makers and community-based initiatives}

Community participation in the decision making process about strategies to manage COVID-19 and other pandemics could be a vital factor to enhance urban resilience [61]. Most cities, including our case study cities, have not fully included communities in the decision making process in the current crisis. Communities and the civil sector felt ignored and forced to surrender temporarily their liberty to move-around and access public spaces in cities [62]. The social capital and community wisdom how their local neighbourhoods function and adapt are an important source of information that could enrich the decision making process together with local government authorities to better cope with the quarantine restrictions and reduce the adverse effects of forced lockdown measures during COVID-19.

In the proximity analysis, there are large areas in the case study cities with very low proximity and accessibility to green areas and public spaces. The analysis also shows that in the densest areas and with fewer area of public space per inhabitant, the level of contagion to COVID-19 is higher. Therefore, public policies oriented towards the provision of more and better public space should be on the agenda for cities in developing countries, with special emphasis on the informal areas most vulnerable to COVID-19.

The vulnerability to develop serious heath complications from COVID-19 is correlated with diseases such as diabetes, heart problems and high blood pressure and lung problems [1]. The rate of occurrence of these diseases is related to urban areas with low accessibility to green areas and active transport (walking, cycling), which promotes car dependency and sedentary lifestyle. Our research showed that large areas of the case study cities, affected by the highest levels of contagions, have public transport disadvantage and low proximity to parks. It is important to understand this relationship between the characteristics of the virus and urban planning, which should more efficiently promote active transportation and exercise in parks and recreational public spaces.

Another important recommendation to local administrations is to collect higher resolution data and made publicly available, to facilitate the efforts of academy and other institutions to provide better insights on the dynamics of pandemic spread or control. Finally, it is also important for cities to provide small scale disaggregated data on COVID-19, in order to understand the possible impacts of urban form and urban features such as the ones explored in this chapter (public space, mobility, density) on the spread and behaviour of the COVID-19 pandemic at neighbourhood or precinct levels. 


\subsection{Conclusions and Future Work}

\subsubsection{Summary of main findings}

The impact of quarantine on the use of homes has been high, although its adaptation has been restricted due to lack of flexibility of housing. The development of new housing that can more easily adapt to new conditions and mix or types of uses to respond to the needs of its inhabitants is needed.

The use of public space has decreased considerably in the three study cities, mostly motivated by access restrictions and lack of confidence in the hygienic safety of public space and facilities. This could have a significant impact on public health, and potentially lead to an increase in the rate of diseases related to sedentary lifestyle and social isolation is expected [1]. Therefore, it is essential to avoid total restrictions (all or nothing approaches) in accessing public space and green areas, and instead promote strategies of capacity control, use of real-time data of public space agglomerations, continuous disinfection of urban and sports furniture and signage for social distancing.

The change of paradigm from face-to-face work and education to virtual work/education will be one of the main factors that will guide urban development in the coming years. This trend was already starting to occur in some cities that have decentralized their areas of employment from the city centre to nodes and secondary activity centres in the city. Steps in this direction have been already taken by some cities such as Melbourne and Paris, aiming to apply the 20-minutes city concept to their current and future urban development plans. But this trend has accelerated during COVID-19.

Proximity to public spaces and green areas has a correlation with the level of contagion in the case study cities, however it is important to take into account the impact of the socioeconomic profile and population density, since these could have more influence on the level of contagions by location according to the results of this research. There are several trade-offs between the advantages of density and the risk of contagion in areas with high traffic and urban density, which should be explored in more detail in order to improve resilience to COVID-19 and future pandemics.

Access to green areas and public recreational spaces is vital to better cope with the restrictions and lifestyle changes caused by the pandemic. The shift towards teleworking and online education has led to an increase in lack of physical activity and face-to-face interaction. Therefore, it does not make sense that in times of pandemic, decisions are made to close urban parks, playgrounds and public spaces, which further confines the population and leaves them without options for socialization, exercising and enjoyment of nature. These are considered essential for good mental and community health. Access to parks and public recreational space must be merely regulated, not prohibited. Authorities need to take advantage of the potential of new technology (such as crowd monitoring and public transport real-time data on commuters) to prevent crowding and increase the continuous disinfection of urban/public spaces and furniture.

\subsubsection{Contributions to research and practice}

Geospatial analysis can contribute to a better management of the COVID-19 pandemic by identifying the most important urban spaces for the community and understanding how the characteristics of each context influence public health and quality of life. After the first wave of the pandemic, COVID-19 control strategies in many cities have been aimed at identifying contagion clusters and selective quarantine of specific areas of the city, which is why it is essential to understand the relationships between the prevalence of contagion of COVID-19 and the urban characteristics at multiple scales of analysis (i.e., zonal, neighbourhood, municipality).

The development of urban centralities or activity hubs that reduce the need for the population for long commute to their jobs, studies, health and recreation areas is one of the strategies that can help reduce the spread of COVID-19, especially in cities with high urban density. The urban sub-centres (centralities) where there is a combination of activities (housing, employment, recreation, health), have the possibility of being more resilient to the impacts of strict quarantine, 
by being able to organize the development of these activities more efficiently and adapted to their special needs. Generic quarantine and general curfew measures applied to cities may result in a worsening of the population's quality of life and economy, while more targeted and customized solutions and measures for neighbourhoods and communities may have a better chance of success.

\subsubsection{Future steps}

The relationship between density and COVID-19 involve several variables that should be further investigated to understand the possible trade-offs between the advantages of density and the management of public transport systems and crowded public spaces, especially in cities with a large percent of its population depending on informal trading in public spaces to secure a living, such as the three cities in our case studies. Also, with better data, we can undertake finer grain analysis and explore urban form variables at block or neighbourhood level. Many cities have been publishing their COVID-19 pandemic data through several portals and dashboards, which help to track the spread of the virus and prepare for second wave and other future pandemics.

The COVID-19 pandemic has highlighted the high vulnerability of cities and communities to manage new forms of risks to public health. Therefore, it is vital to learn from the lessons from the best (and also worst) management strategies that different countries and cities have applied to cope with the pandemic, and be able to adapt quickly to new conditions and be more resilient to future pandemic and other threats. The development of healthier cities, with more robust health infrastructure and multi-mode active transport networks and generous green zones should be included in the planning agenda of cities to reduce the social and economic impacts of current and future quarantine restrictions in cities.

\section{Acknowledgements}

The authors wish to acknowledge the sponsorship and research grant funded by Urban Mapping Agency (UMA) and BuroDAP in Colombia. Also, we thank the collaboration of associated researchers to this research project: Arch. Manuel Bobadilla, GIS Analyst Angga Syfarianto, Roxane Dufresne and Arch. Diego Torres for their valuable contributions to data analysis.

\section{References}

[1] WHO. Strengthening Preparedness for COVID-19 in Cities and Urban Settings Interim Guidance for Local Authorities. W. H. Organization, Ed., 2020.

[2] Pablo Cabrera-Barona and Andrea Carrión. Voiding Public Spaces, Enclosing Domestic Places: Place Attachment at the Onset of the Pandemic in Quito, Ecuador. Journal of Latin American Geography, Ahead of Print: JLAG Perspectives, 2020. doi: 10.1353/lag.0.0145.

[3] Isabel Duque Franco, Catalina Ortiz, Jota Samper, and Gynna Millan. Mapping repertoires of collective action facing the COVID-19 pandemic in informal settlements in Latin American cities. Environment and Urbanization, 2020. URL https://doi.org/10.1177/0956247820944823.

[4] R. A Matthew and B Mcdonald. Cities under Siege: Urban Planning and the Threat of Infectious. Journal of the American Planning Association, 72(1), 109-117, 2006.

[5] Xin Li, Lin Zhou, Tao Jia, Ran Peng, Xiongwu Fu, and Yuliang Zou. Associating COVID-19 Severity with Urban Factors: A Case Study of Wuhan. Research Square, 2020. URL https://doi.org/10.21203/rs.3.rs$34863 / \mathrm{v} 1$.

[6] José Antonio Belso-Martínez, Alicia Mas-Tur, Mariola Sánchez, and María José López-Sánchez. The COVID 19 response system and collective social service provision. Strategic network dimensions and proximity considerations. Service Business, 2020. URL https://doi.org/10.1007/s11628-020-00421-w. 
[7] Ashley Wendell Kranjac and Dinko Kranjac. County-level factors influence the trajectory of covid-19 incidence. medRxiv and bioRxiv, 2020. doi: 10.1101/2020.05.05.20092254.

[8] C. Boyko and C. Boyko. Progress in Planning. Annu Rev Ecol Evol Syst, 1(76):1-61, 2011.

[9] Shlomo, P. Lamson-Hall, S. Shingad, S. Kumar, and Z. Gonzalez Blanco. Anatomy of Density I: Measurable Factors that Together Constitute Urban Density. NYU Marron Institute of Urban Management, 2020. URL https://marroninstitute.nyu.edu/papers/anatomy-of-density-i-measurablefactors-that-together-constitute-urban-density.

[10] Shima Hamidi, Sadegh Sabouri, and Reid Ewing. Does Density Aggravate the COVID-19 Pandemic? Journal of the American Planning Association. Journal of the American Planning Association, 2020. doi: 10.1080/ 01944363.2020 .1777891$.

[11] Helen VS Cole, Isabelle Anguelovski, Francesc Baró, Melissa García-Lamarca, Panagiota Kotsila, Carmen Pérez del Pulgar, Galia Shokry, and Margarita Triguero-Mas. The COVID-19 pandemic: power and privilege, gentrification, and urban environmental justice in the global north. Cities \& Health, 2020. doi: 10.1080/ 23748834.2020 .1785176 .

[12] Matheus T Baumgartner, Fernando M Lansac-Toha, Marco Tulio P Coelho, Ricardo Dobrovolski, and Jose Alexandre F Diniz-Filho. Social distancing and movement constraint as the most likely factors for COVID-19 outbreak control in Brazil. meRxiv Health Cities, 2020. doi: 10.1101/2020.05.02.20088013.

[13] Ibraheem M Karaye and Jennifer A Horney. The impact of social vulnerability on covid-19 in the us: an analysis of spatially varying relationships. American Journal of Preventive Medicine, 59(3):317-325, 2020. doi: $10.1016 /$ j.amepre.2020.06.006.

[14] A Polko. Public space development in the context of urban and regional resilience. Cambridge Journal of Regions, Economy and Society, 3(1), 2010.

[15] L. Alter. Urban design after the coronavirus. Treehugger, 2020. URL https://www.treehugger.com/urbandesign/urban-design-after-coronavirus.html. accessed 4.9.20.

[16] R. Florida. We'll Need To Reopen Our Cities. But Not Without Making Changes First. CityLab, 2020.

[17] H. Null, S. anad Smith. COVID-19 Could Affect Cities for Years. Here Are 4 Ways They're Coping Now. TheCityFix: World Resource Institute (WRI), 2020.

[18] D. Roberts. How to make a city livable during lockdown. Vox, 2020.

[19] R. van der Berg. How Will COVID-19 Affect Urban Planning? TheCityFix, 2020.

[20] Mick Lennon. Green space and the compact city: planning issues for a 'new normal'. Cities $E S$ Health, 2020. doi: $10.1080 / 23748834.2020 .1778843$.

[21] Yuwen Lu, Guofang Zhai, Shutian Zhou, and Yijun Shi. Risk reduction through urban spatial resilience: A theoretical framework. Human and Ecological Risk Assessment: An International, 2020. doi: 10.1080/ 10807039.2020.1788918.

[22] UNHABITAT. What is urban resilience. Urban Resilience Hub, 2019. URL https://urbanresiliencehub. org/what-is-urban-resilience/.

[23] CEPAL and S. Huenchuan. COVID-19 Recomendaciones generales para la atención a personas mayores desde una perspectiva de derechos humanos. 2020. URL http://repositorio.uasb.edu.bo/handle/54000/1122.

[24] Dadep. Primer Reporte de Indicadores. 2018.

[25] WRI MÉXICO. Manual "Espacio Público y Vida Pública. 2016. URL https://wriciudades.org/research/ publication/manual-espacio-p\%C3\%BAblico-y-vida-p\%C3\%Bablica.

[26] INEC. Actualización metodológica:Empleo en el sector informal yla clasificación de los ocupadossegún sectores. 2015. URL https://www.ecuadorencifras.gob.ec/documentos/web-inec/EMPLEO/2015/Junio-2015/ Metogologia_Informalidad/notatecnica.pdf.

[27] N. Clichevsky. Informalidad y segregaciónurbana en América Latina. Unaaproximación. medio ambiente y desarrollo. 2000. URL https://repositorio.cepal.org/bitstream/handle/11362/5712/S00100859.pdf?sequence= 1.

[28] R. Rocha, F. Sánchez, and L. García. Ventas callejeras y espacio público: efectos sobre el comercio de Bogotá. Desarrollo y Sociedad, 2009. URL http://www.scielo.org.co/scielo.php?script=sci_arttext\&pid= S0120-35842009000100007\&lng=en\&tlng=es.

[29] Michael Janoschka and Jorge Sequera. Gentrification in Latin America: addressing the politics and geographies of displacement. Urban Geography, 1(20), 37(8):1-20, 2016. doi: 10.1080/02723638.2015.1103995. 
[30] ILO. Woman and Men the informal Economy: a statistical picture. International Labour Organization. 2018. URL https://www.ilo.org/wcmsp5/groups/public/---dgreports/---dcomm/documents/publication/wcms_ 626831.pdf.

[31] NEGI. Estadísticas de Informalidad. México, Nuevas Estadísticas de Informalidad laboral. 2020.

[32] DANE. Empleo Informal y Seguridad Social. 2019. URL https://www.dane.gov.co/index.php/estadisticaspor-tema/salud/informalidad-y-seguridad-social/empleo-informal-y-seguridad-social-historicos.

[33] ACNUR. Datos Básicos Refugiados. 2020. URL https://www.acnur.org/datos-basicos.html.

[34] Kishinchand Poornima Wasdani and Ajnesh Prasad. The impossibility of social distancing among the urban poor: the case of an indian slum in the times of covid-19. Local Environment. The International Journal of Justice and Sustainability, 2020. doi: 10.1080/13549839.2020.1754375.

[35] CEPAL. Estudio Económico de América Latina y el Caribe 2015: desafíos para impulsar el ciclo de inversión con miras a reactivar el crecimiento. CEPAL, 2015. URL https://www.cepal.org/es/publicaciones/38713estudio-economico-america-latina-caribe-2015-desafios-impulsar-ciclo-inversion.

[36] Jordi Honey-Roses, Isabelle Anguelovski, Vincent Chireh, Carolyn Daher, Cecil Konijnendijk, Jill Litt, M. Nieuwenhuijsen, et al. The impact of COVID-19 on public space: an early review of the emerging questions - design, perceptions and inequities. Cities 8 Health, 2020.

[37] Gehl. Public Space \& Public Life during COVID-19 Survey Report. Supported by Realdania and the City of Copenhagen, 2020. URL https://covid19.gehlpeople.com/.

[38] George J Musa, Po-Huang Chiang, Tyler Sylk, Rachel Bavley, William Keating, Bereketab Lakew, Hui-Chen Tsou, and Christina W Hoven. Use of GIS mapping as a public health tool-from cholera to cancer. Health services insights, 2013. doi: 10.4137/HSI.S10471.

[39] I. Franch-Pardo, B. M.Napoletano, and F. Rosete-Verges. Spatial analysis and GIS in the study of COVID-19. A review. Science of The Total Environment, 2013. URL https://doi.org/10.1016/j.scitotenv.2020.140033.

[40] D. Kasraian, K. Maat, and B. Van Wee. The impact of urban proximity, transport accessibility and policy on urban growth: A longitudinal analysis over five decades. Environment and Plannig B: Urban Analytics and City Science, 2017.

[41] Yuliang Zhang, Wenxiang Li, Haopeng Deng, and Ye Li. Evaluation of Public Transport-Based Accessibility to Health Facilities considering Spatial Heterogeneity. Methods and Technologies for Next-Generation Public Transport Planning and Operations, 2020. doi: 10.1155/2020/7645153.

[42] Hugh Barton. Land use planning and health and well-being. Land Use Policy, 2009. doi: https://doi.org/ 10.1016/j.landusepol.2009.09.008.

[43] Joseph Sakshaug. Important considerations when analyzing health survey data collected using a complex sample design. American Journal of Public Health, pages 15-16, 2014. doi: 10.2105/AJPH.2013.301515.

[44] Chen Zhong, Xianfeng Huang, Stefan Müller Arisona, and Gerhard Schmitt. Identifying Spatial Structure of Urban Functional Centers Using Travel Survey Data: A Case Study of Singapore. Conference: Proceedings of The First ACM SIGSPATIAL International Workshop on Computational Models of Place (COMP'13), 2013. doi: $10.1145 / 2534848.2534855$.

[45] J. F. Sánchez-Rada and C. A. Iglesias. Social context in sentiment analysis: Formal definition, overview of current trends and framework for comparison. Information Fusion, 2019. doi: https://doi.org/10.1016/j. inffus.2019.05.003.

[46] GIS Documentation. Coste de distancia (Spatial Analyst). ArcGis Pro, 2016. URL https://pro.arcgis.com/ es/pro-app/tool-reference/spatial-analyst/cost-distance.htm.

[47] Mark Stevenson, Jason Thompson, Thiago Hérick de Sá, Reid Ewing, Dinesh Mohan, McClure, et al. Land use, transport, and population health: estimating the health benefits of compact cities. Urban Design, Transport, and Health, pages 2925-2935, 2016. doi: 10.1016/S0140-6736(16)30067-8.

[48] E. Rodríguez-Izquierdo, S. Pérez-Jiménez, L. Merino-Pérez, and M. (s.f.) Mazari-Hiriart. Spatial analysis of COVID-19 and inequalities in Mexico City. URL https://www.un.org/development/desa/dpad/wp-content/ uploads/sites/45/COVID-19-Mexico-City.pdf.

[49] PROFAMILIA. Health services inequalities affecting the Venezuelan migrant and refugee population in Colombia. Profamila, 2020. URL https://profamilia.org.co/wp-content/uploads/2020/06/Health-servicesinequalities-affecting-the-Venezuelan-migrant-and-refugee-population-in-Colombia-how-to-improvethe-local-response-to-the-humanitarian-emergency.pdf.

[50] PROFAMILIA. Health services inequalities affecting the Venezuelan migrant and refugee population in Colombia. Profamila, 2020. URL https://profamilia.org.co/wp-content/uploads/2020/06/Health-servicesinequalities-affecting-the-Venezuelan-migrant-and-refugee-population-in-Colombia-how-to-improvethe-local-response-to-the-humanitarian-emergency.pdf. 
[51] A. Bedimo-Rung, A. Mowen, and D.l Cohen. The significance of parks to physical activity and public health: a conceptual model. Am J Prev Med, 2005. doi: 10.1016/j.amepre.2004.10.024.

[52] C. Moreno. Prossimità a parigi / proximity in paris. DOMUS, 2020. URL http://www. moreno-web.net/domusprossimita-a-parigi-proximity-in-paris-edition-juin-2020/.

[53] Victoria State Government. Plan Melbourne 2017-2020. Social Science ES Medicine, 2017. URL https: //vpa.vic.gov.au/strategy-guidelines/plan-melbourne/.

[54] N. Corbett. Small is beautiful: Planning for a post-Covid world. Transforming Cities, 2020. URL https: //www.transformingcities.co.uk/small-is-beautiful-planning-for-a-post-coved-world/.

[55] Villerías Salinas, G. S., Nochebuena, and A. Uriostegui Flores. Análisis espacial de vulnerabilidad y riesgo en salud por COVID-19 en el estado de Guerrero, México. Posición. Análisis geográfico del COVID-19. 2020.

[56] S Michelle Driedger, Anita Kothari, Jason Morrison, Michael Sawada, Eric J Crighton, and Ian D Graham. Correction: Using participatory design to develop (public) health decision support systems through gis. International Journal of Health Geographics, page 53, 2007. URL https://ij-healthgeographics. biomedcentral.com/articles/10.1186/1476-072X-6-53.

[57] Google. Google Community Reports. 2020. URL https://www.google.com/covid19/mobility/.

[58] Mario Coccia. Factors determining the diffusion of covid-19 and suggested strategy to prevent future accelerated viral infectivity similar to covid. Science of the Total Environment, 2020. doi: 10.1016/j.scitotenv. 2020.138474 .

[59] Kim Dovey and Elek Pafka. What is walkability? The urban dma. Urban studies, 2020. doi: 10.1177/ 0042098018819727.

[60] R. Marino Zamudio. Assessing the impact of urban form on the energy consumption and Green House Gas (GHG) emissions in Metropolitan Melbourne. PhD Thesis, Universidad de Melbourne, Melbourne, 2020. URL https://minerva-access.unimelb.edu.au/handle/11343/241479.

[61] Ayyoob Sharifi. A critical review of selected tools for assessing community resilience. Ecological Indicators, pages 629-647, 2016. doi: 10.1016/j.ecolind.2016.05.023.

[62] Harvard Gazzete. Strong signals: Study findings support use of county-level cell phone location data as tool to estimate future trends of the COVID-19 pandemic. 2020. URL https://news.harvard.edu/gazette/story/ 2020/08/cell-phone-location-data-can-help-monitor-covid-19-rates/. 
$\Longrightarrow$ Taylor \& Francis Taylor \& Francis Group

http://taylorandfrancis.com 